\title{
Integrated nutrient management of rapeseed (Brassica campestris L. var. yellow sarson) grown in a typic haplaquept soil
}

\author{
Sayan Majumder ${ }^{*}$, Tapas Kumar Halder ${ }^{2}$ and Dipankar Saha ${ }^{1}$ \\ ${ }^{1}$ Department of Agricultural Chemistry and Soil Science, Bidhan Chandra Krishi Viswavidyalaya, Mohanpur - \\ 741252, District-Nadia (West Bengal), INDIA \\ ${ }^{2}$ Assistant Director of Agriculture (Research), State Soil Testing Laboratory, Tollygaunge, Kolkata-700040 (West \\ Bengal), INDIA \\ *Corresponding author. E-mail: 1991sayan@gmail.com
}

Received: August 10, 2016; Revised received: February 21, 2017; Accepted: May 17, 2017

\begin{abstract}
The present investigation was conducted to study the influence of integrated nutrient management on fertility build up in a Typic Haplaquept soil as well as its effect on yield and quality parameters of rapeseed (Brassica campestris L. var. yellow sarson). Treatments comprised of recommended doses of N, P and K fertilizers (RDF) in presence and absence of FYM along with different doses of $S$ and $\mathrm{Zn}$ either alone or in combination. Results revealed that in general, available $\mathrm{N}, \mathrm{P}, \mathrm{K}, \mathrm{S}$ and $\mathrm{Zn}$ in soil decreased with increase in the period of crop growth. Addition of FYM increased organic carbon content in soils (upto $104.98 \mathrm{~g} \mathrm{~kg}^{-1}$ increase over initial value). Application of elemental S and Zn-EDTA increased $\mathrm{SO}_{4}^{-2}$ content (upto $101.03 \mathrm{~kg} \mathrm{ha}^{-1}$ increase over initial value) in S-treated and DTPA extractable $\mathrm{Zn}$ content (upto $0.3 \mathrm{mg} \mathrm{kg}^{-1}$ increase over initial value) in Zn-treated systems respectively. Combined application of higher doses of $S$ and $Z n$ along with FYM and recommended doses of $N, P$ and $K$ fertilizers increased N, P, K, S and Zn uptake by rapeseed crop. Highest seed yield (14.2 q ha ${ }^{-1}$ ) as well as oil (43.2\%) and protein contents $(21.82 \%)$ were recorded in rapeseed which received comparatively higher doses of $\mathrm{S}$ and $\mathrm{Zn}$ along with FYM and RDF.
\end{abstract}

Keywords: FYM, INM, Oil and protein content, RDF, Sulphur and zinc

\section{INTRODUCTION}

Integrated nutrient management (INM) aims at maintenance of plant nutrient supply to achieve a given level of crop production by optimizing the benefits from all possible sources of plant nutrients in an integrated manner, appropriate to cropping system and farming situation (Mahajan and Sharma, 2005; Rao and Reddy, 2005). Crop productivity is increased due to combined application of chemical fertilizer and organic manures. Such combination contributed to the improvement of physical, chemical and biological properties of soil (Esilaba et al., 2004).

Rapeseed-mustard occupies the second position in oilseeds next to the groundnut. Among the Brassica family, Indian rapeseed (Brassica campestrisL. var. yellow sarson) is the $2^{\text {nd }}$ most important oil-yielding crop after Indian mustard [Brassica juncea (L.) Czern. and Coss.] followed by toria (Brassica campestris var. toria). Mustard and sarson group of plants are cultivated in 26 states in the northern and eastern plains of the country, occupying 7.22 mha areas with 7.96 million tones of production at $11.02 \mathrm{q} \mathrm{ha}^{-1}$ productivity (Rai et al., 2016). India holds a premier position in rapeseedmustard economy of the world with 3rd rank in both area and production (Rai et al., 2016).
The productivity of Indian rapeseed is quite low due to sub-optimal application of fertilizers and cultivation on marginal lands under rainfed conditions. Intensive cultivation and use of unbalanced and inadequate fertilizers accompanied by restricted use of organic manures have made the soils not only deficient in the nutrients, but also deteriorated the soil health. All these things resulted in poor crop yield of rapeseed in terms of quantity and quality. In order to supply all the nutrients in adequate amount and to maintain its good health, it is necessary to use organic sources like FYM in combination with fertilizers. They not only supply macronutrients but also meet the demand of micronutrients, besides improving soil health (Arbad and Ismail, 2011).

It was reported that long term combined application of zinc, sulfur and along with FYM significantly increased crop yield, uptake and availability of micronutrients in soil over chemical fertilizer alone (Ameta $e t$ al., 2014). Researchers (Gupta et al., 2014) also reported that integrated nutrient management increased the economic yield of mustard-based cropping system by $35 \%$ than that without FYM treatment.

The present experiment was, therefore, conducted to study the influence of integrated nutrient management (especially FYM, S and Zn) on soil fertility build up as 
well as yield and quality improvement of rapeseed.

\section{MATERIALS AND METHODS}

The investigation was conducted with rapeseed (B9 / Binoy variety) in a farmer's field situated at Kalibazar, Chakdah block, Nadia, West Bengal, India $\left(23.08^{\circ} \mathrm{N}\right.$, $88.53^{\circ} \mathrm{E}, 11 \mathrm{~m}$ above MSL) during November, 2013 to February, 2014. In the present investigation, both organic (FYM) and inorganic fertilizers (N, P, and K) were applied including sulphur and zinc as treatment combinations. Initial composite soil sample $(0-15 \mathrm{~cm})$ of the field was collected and analyzed for different physical, chemical and physico-chemical properties using standard methodologies. The characteristics of the initial soil samples were: $\mathrm{pH} 6.4$, EC $0.160 \mathrm{dSm}^{-1}$, Org. C $0.88 \%$, Clay $65.2 \%$, Textural class clay loam,

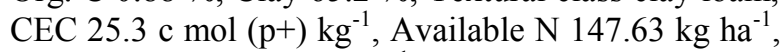
Available $\mathrm{P}_{2} \mathrm{O}_{5} 70.5 \mathrm{~kg} \mathrm{ha}^{-1}$, Available $\mathrm{K}_{2} \mathrm{O} 245.21 \mathrm{~kg}$ $\mathrm{ha}^{-1}$, Available $\mathrm{SO}_{4}{ }^{-2} 23.75 \mathrm{~kg} \mathrm{ha}^{-1}$, DTPA-extractable

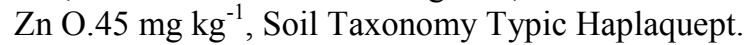

Altogether 10 treatments were employed in the present investigation, each with 3 replications. The treatments were: $\mathrm{T}_{0}=$ Control, $\mathrm{T}_{1}=\mathrm{T}_{0}+\mathrm{FYM}, \mathrm{T}_{2}=\mathrm{T}_{0}+\mathrm{FYM}+$ $\mathrm{Zn}_{1}, \mathrm{~T}_{3}=\mathrm{T}_{0} \mathrm{FYM}+\mathrm{Zn}_{2}, \mathrm{~T}_{4}=\mathrm{T}_{0}+\mathrm{FYM}+\mathrm{S}_{1}, \mathrm{~T}_{5}=\mathrm{T}_{0}$ $+\mathrm{FYM}+\mathrm{S}_{2}, \mathrm{~T}_{6}=\mathrm{T}_{0}+\mathrm{FYM}+\mathrm{Zn}_{1}+\mathrm{S}_{1}, \mathrm{~T}_{7}=\mathrm{T}_{0}+\mathrm{FYM}$ $+\mathrm{Zn}_{1}+\mathrm{S}_{2}, \mathrm{~T}_{8}=\mathrm{T}_{0}+\mathrm{FYM}+\mathrm{Zn}_{2}+\mathrm{S}_{1,} \mathrm{~T}_{9}=\mathrm{T}_{0}+\mathrm{FYM}$ $+\mathrm{Zn}_{2}+\mathrm{S}_{2}$. All treatments received recommended doses of $\mathrm{N}, \mathrm{P}_{2} \mathrm{O}_{5}$ and $\mathrm{K}_{2} \mathrm{O}$ at 80:40:40 $\mathrm{kg} \mathrm{ha}^{-1}$ through Urea, SSP and MOP respectively. Two doses of $\mathrm{S}$ as $\mathrm{S}_{1}$ at $20 \mathrm{~kg} \mathrm{ha}^{-1}$ and $\mathrm{S}_{2}$ at $40 \mathrm{~kg} \mathrm{ha}^{-1}$ as well as two doses of $\mathrm{Zn}$ as $\mathrm{Zn}_{1}$ at $5 \mathrm{~kg} \mathrm{ha}{ }^{-1}$ and $\mathrm{Zn}_{2}$ at $10 \mathrm{~kg} \mathrm{ha}{ }^{-1}$ were incorporated in the treatment combinations. Full dose of $\mathrm{P}_{2} \mathrm{O}_{5}, \mathrm{~K}_{2} \mathrm{O}, \mathrm{S}, \mathrm{Zn}$ and half of the total $\mathrm{N}$ were applied at the time of final land preparation and the remaining half of the $\mathrm{N}$ was applied at about 30 days after sowing and just after final weeding and thinning.
The full dose of FYM at $5 \mathrm{t} \mathrm{ha}^{-1}$ was applied at the time of primary land preparation as per treatment combinations.

Soil samples were collected from each of 30 plots (15$30 \mathrm{~cm})$ at flowering (30 DAS), pod formation (60 DAS) and harvesting stage (90 DAS) of the rapeseed. The samples were air dried for removal of moisture and analyzed for oxidizable organic carbon, available $\mathrm{N}$, available $\mathrm{P}_{2} \mathrm{O}_{5}$, available $\mathrm{K}_{2} \mathrm{O}$, available $\mathrm{SO}_{4}{ }^{-2}$ and DTPA-extractable $\mathrm{Zn}$ following standard methods. After harvesting, the plant samples were oven dried and analyzed for total N (Piper, 1967 1942), total P (Jackson, 1973), total K by flame photometer, total S (Chesnin and Yien, 1951) and total $\mathrm{Zn}$ by Atomic Absorption Spectrophotometer. Seeds were analyzed for oil content with the help of Soxhlet's extraction method (Soxhlet, 1879) and protein content by Lowry's soluble protein determination method (Lowry et al., 1951). Seed yield was recorded after harvest.

Data of soil, plant and grain samples were analyzed statistically at different growth stages of rapeseed crop using Microsoft Excel. Parameters like Critical Difference (CD) at $5 \%$ level (for test of significance), SEM i.e. Standard Error Mean were calculated.

\section{RESULTS AND DISCUSSION}

Irrespective of treatments, in general, available $\mathrm{N}$ significantly increased from flowering to pod formation stage and thereafter decreased at harvesting stage of the rapeseed crop (Table 1). However, available $\mathrm{N}$ tended to decrease from flowering to harvesting stage in control plots. The increase in available $\mathrm{N}$ from flowering to pod formation is due to mineralization of FYM and accumulation of available $\mathrm{N}$ in soils. The results find support of earlier investigation carried out

Table 1. Changes in the amount $\left(\mathrm{kgha}^{-1}\right)$ of available $\mathrm{N}, \mathrm{P}_{2} \mathrm{O}_{5}$ and $\mathrm{K}_{2} \mathrm{O}$ in soils at different growth stages of rapeseed amended with different treatment combinations.

\begin{tabular}{|c|c|c|c|c|c|c|c|c|c|}
\hline \multirow{3}{*}{ Treatments } & \multicolumn{3}{|c|}{ Available $\mathbf{N}$} & \multicolumn{3}{|c|}{ Available $\mathbf{P}_{2} \mathbf{O}_{5}$} & \multicolumn{3}{|c|}{ Available $\mathbf{K}_{2} \mathbf{O}$} \\
\hline & \multicolumn{3}{|c|}{ Stages of crop growth } & \multicolumn{3}{|c|}{ Stages of crop growth } & \multicolumn{3}{|c|}{ Stages of crop growth } \\
\hline & Flowering & $\begin{array}{c}\text { Pod } \\
\text { formation }\end{array}$ & Harvesting & Flowering & $\begin{array}{c}\text { Pod } \\
\text { formation }\end{array}$ & Harvesting & Flowering & $\begin{array}{c}\text { Pod } \\
\text { formation }\end{array}$ & Harvesting \\
\hline $\mathrm{T}_{0}=$ Soil & 191.76 & 165.40 & 139.49 & 78.11 & 61.54 & 51.21 & 261.53 & 286.17 & 253.72 \\
\hline $\mathrm{T}_{1}=$ Soil $+\mathrm{FYM}$ & 200.86 & 220.85 & 206.85 & 91.25 & 77.78 & 66.20 & 284.62 & 298.81 & 268.44 \\
\hline $\mathrm{T}_{2}=\mathrm{T}_{1}+\mathrm{Zn}_{1}$ & 212.08 & 221.87 & 208.69 & 102.21 & 88.65 & 76.65 & 292.72 & 302.05 & 275.30 \\
\hline $\mathrm{T}_{3}=\mathrm{T}_{1}+\mathrm{Zn}_{2}$ & 217.93 & 254.98 & 234.44 & 106.74 & 91.18 & 83.95 & 308.18 & 326.77 & 275.49 \\
\hline $\mathrm{T}_{4}=\mathrm{T}_{1}+\mathrm{S}_{1}$ & 212.05 & 258.83 & 223.29 & 112.21 & 105.12 & 89.84 & 316.32 & 320.49 & 279.63 \\
\hline $\mathrm{T}_{5}=\mathrm{T}_{1}+\mathrm{S}_{2}$ & 227.14 & 236.00 & 191.73 & 120.97 & 112.74 & 97.74 & 327.08 & 337.10 & 282.96 \\
\hline $\mathrm{T}_{6}=\mathrm{T}_{2}+\mathrm{S}_{1}$ & 241.80 & 254.72 & 204.80 & 121.24 & 118.15 & 101.14 & 335.92 & 332.32 & 289.61 \\
\hline $\mathrm{T}_{7}=\mathrm{T}_{2}+\mathrm{S}_{2}$ & 236.93 & 265.11 & 221.10 & 123.15 & 120.89 & 105.21 & 345.69 & 340.05 & 295.58 \\
\hline $\mathrm{T}_{8}=\mathrm{T}_{3}+\mathrm{S}_{1}$ & 251.63 & 272.62 & 233.39 & 126.45 & 119.65 & 111.14 & 359.18 & 343.93 & 297.84 \\
\hline $\mathrm{T}_{9}=\mathrm{T}_{3}+\mathrm{S}_{2}$ & 262.37 & 296.71 & 248.46 & 130.78 & 121.34 & 113.78 & 371.88 & 348.21 & 299.38 \\
\hline Mean & 225.46 & 244.71 & 211.23 & 111.31 & 101.70 & 89.69 & 320.31 & 323.59 & 281.80 \\
\hline SEM & 4.67 & 3.02 & 2.73 & 2.26 & 1.87 & 1.96 & 4.85 & 3.84 & 3.12 \\
\hline $\mathrm{CD}(5 \%)$ & 13.88 & 8.98 & 8.12 & 6.71 & 5.56 & 5.823 & 14.42 & 11.40 & 9.27 \\
\hline
\end{tabular}

Where, FYM = Farm Yard Manure at $5 \mathrm{t} \mathrm{ha}^{-1}, \mathrm{Zn}_{1}=\mathrm{Zn}$ at $5 \mathrm{~kg} \mathrm{ha}^{-1}$ as $\mathrm{Zn}-\mathrm{EDTA}, \mathrm{Zn}_{2}=\mathrm{Zn}$ at $10 \mathrm{~kg} \mathrm{ha}^{-1}$ as Zn-EDTA, $\mathrm{S}_{1}=\mathrm{S}$ at $20 \mathrm{~kg} \mathrm{ha}^{-1}$ as Elemental S, $\mathrm{S}_{2}=\mathrm{S}$ at $40 \mathrm{~kg} \mathrm{ha}^{-1}$ as Elemental $\mathrm{S}^{\prime \prime}$ 
Table 2. Changes in the amount of Oxidizable organic carbon $\left(\mathrm{g} \mathrm{kg}^{-1}\right)$, available $\mathrm{SO}_{4}^{-2}\left(\mathrm{~kg} \mathrm{ha}^{-1}\right)$ and DTPA-extractable Zn $\left(\mathrm{mg} \mathrm{kg}^{-1}\right)$ in soils at different growth stages of rapeseed amended with different treatment combinations.

\begin{tabular}{|c|c|c|c|c|c|c|c|c|c|}
\hline \multirow{2}{*}{ Treatments } & \multicolumn{3}{|c|}{$\begin{array}{c}\text { Oxidizable organic carbon } \\
\text { Stages of plant growth }\end{array}$} & \multicolumn{3}{|c|}{$\begin{array}{c}\text { Available } \mathrm{SO}_{4}^{-2} \\
\text { Stages of plant growth }\end{array}$} & \multicolumn{3}{|c|}{$\begin{array}{c}\text { DTPA-extractable Zn } \\
\text { Stages of plant growth }\end{array}$} \\
\hline & Flowering & $\begin{array}{c}\text { Pod } \\
\text { formation }\end{array}$ & Harvesting & Flowering & $\begin{array}{c}\text { Pod } \\
\text { formation }\end{array}$ & Harvesting & Flowering & $\begin{array}{c}\text { Pod } \\
\text { formation }\end{array}$ & Harvesting \\
\hline $\mathrm{T}_{0}=$ Soil & 6.42 & 6.23 & 6.87 & 27.35 & 20.66 & 22.63 & 0.50 & 0.52 & 0.36 \\
\hline $\mathrm{T}_{1}=$ Soil $+\mathrm{FYM}$ & 7.54 & 6.71 & 7.10 & 33.54 & 25.61 & 26.38 & 0.55 & 0.59 & 0.40 \\
\hline $\mathrm{T}_{2}=\mathrm{T}_{1}+\mathrm{Zn}_{1}$ & 7.41 & 7.82 & 7.89 & 35.28 & 30.55 & 26.41 & 0.66 & 0.69 & 0.45 \\
\hline $\mathrm{T}_{3}=\mathrm{T}_{1}+\mathrm{Zn}_{2}$ & 8.17 & 7.55 & 8.65 & 37.02 & 30.47 & 28.77 & 0.70 & 0.74 & 0.48 \\
\hline $\mathrm{T}_{4}=\mathrm{T}_{1}+\mathrm{S}_{1}$ & 8.61 & 6.76 & 8.83 & 42.20 & 36.32 & 32.26 & 0.73 & 0.74 & 0.56 \\
\hline $\mathrm{T}_{5}=\mathrm{T}_{1}+\mathrm{S}_{2}$ & 8.63 & 7.19 & 8.86 & 45.39 & 40.02 & 33.92 & 0.78 & 0.79 & 0.59 \\
\hline $\mathrm{T}_{6}=\mathrm{T}_{2}+\mathrm{S}_{1}$ & 8.18 & 7.83 & 8.75 & 47.13 & 40.24 & 36.10 & 0.85 & 0.80 & 0.62 \\
\hline $\mathrm{T}_{7}=\mathrm{T}_{2}+\mathrm{S}_{2}$ & 7.68 & 6.67 & 7.87 & 48.57 & 42.91 & 38.34 & 0.88 & 0.82 & 0.69 \\
\hline $\mathrm{T}_{8}=\mathrm{T}_{3}+\mathrm{S}_{1}$ & 8.50 & 8.28 & 9.74 & 49.12 & 43.52 & 39.32 & 0.93 & 0.87 & 0.73 \\
\hline $\mathrm{T}_{9}=\mathrm{T}_{3}+\mathrm{S}_{2}$ & 8.71 & 8.62 & 9.80 & 50.07 & 42.96 & 40.12 & 0.94 & 0.89 & 0.75 \\
\hline Mean & 7.99 & 7.37 & 8.33 & 41.57 & 35.32 & 32.43 & 0.75 & 0.75 & 0.56 \\
\hline SEm & 0.02 & 0.03 & 0.04 & 1.99 & 1.55 & 1.15 & 0.01 & 0.01 & 0.01 \\
\hline $\mathrm{CD}(5 \%)$ & 0.07 & 0.08 & 0.11 & 5.82 & 4.60 & 3.43 & 0.03 & 0.04 & 0.03 \\
\hline
\end{tabular}

Where, FYM $=$ Farm Yard Manure at $5 \mathrm{tha}^{-1}, \mathrm{Zn}_{1}=\mathrm{Zn}$ at $5 \mathrm{~kg} \mathrm{ha}^{-1}$ as Zn-EDTA, $\mathrm{Zn}_{2}=\mathrm{Zn}$ at $10 \mathrm{~kg} \mathrm{ha}^{-1}$ as Zn-EDTA, $\mathrm{S}_{1}=\mathrm{S}$ at $20 \mathrm{~kg} \mathrm{ha}^{-1}$ as Elemental S, $\mathrm{S}_{2}=\mathrm{S}$ at $40 \mathrm{~kg} \mathrm{ha}^{-1}$ as Elemental S

Table 3. N, P, K, S and Zn uptake by stover at harvest of rapeseed grown under different treatment combinations.

\begin{tabular}{|c|c|c|c|c|c|c|c|c|c|c|}
\hline \multirow[b]{2}{*}{ Treatments } & \multicolumn{2}{|c|}{ Nitrogen } & \multicolumn{2}{|c|}{ Phosphorus } & \multicolumn{2}{|c|}{ Potassium } & \multicolumn{2}{|c|}{ Sulphur } & \multicolumn{2}{|c|}{ Zinc } \\
\hline & $\%$ & $\begin{array}{l}\text { Uptake } \\
\left(\mathrm{kg} \mathrm{ha}^{-1}\right)\end{array}$ & $\%$ & $\begin{array}{l}\text { Uptake } \\
\left(\mathrm{kg} \mathrm{ha}^{-1}\right)\end{array}$ & $\%$ & $\begin{array}{c}\text { Uptake } \\
\left(\mathrm{kg} \mathrm{ha}^{-1}\right)\end{array}$ & $\%$ & $\begin{array}{l}\text { Uptake } \\
\left(\mathrm{kg} \mathrm{ha}^{-1}\right)\end{array}$ & $\%$ & $\begin{array}{l}\text { Uptake } \\
\left(\mathrm{kg} \mathrm{ha}^{-1}\right)\end{array}$ \\
\hline $\mathrm{T}_{0}=$ Soil & 0.31 & 8.86 & 0.10 & 2.86 & 0.41 & 11.74 & 0.15 & 4.29 & 0.0040 & 0.1143 \\
\hline $\mathrm{T}_{1}=$ Soil $+\mathrm{FYM}$ & 0.37 & 11.07 & 0.12 & 3.60 & 0.50 & 14.96 & 0.17 & 5.09 & 0.0042 & 0.1256 \\
\hline $\mathrm{T}_{2}=\mathrm{T}_{1}+\mathrm{Zn}_{1}$ & 0.42 & 12.94 & 0.13 & 4.02 & 0.58 & 17.85 & 0.19 & 5.85 & 0.0046 & 0.1438 \\
\hline $\mathrm{T}_{3}=\mathrm{T}_{1}+\mathrm{Zn}_{2}$ & 0.50 & 16.26 & 0.13 & 4.24 & 0.61 & 19.84 & 0.19 & 6.06 & 0.0050 & 0.1627 \\
\hline $\mathrm{T}_{4}=\mathrm{T}_{1}+\mathrm{S}_{1}$ & 0.53 & 18.54 & 0.14 & 4.94 & 0.66 & 23.04 & 0.23 & 8.07 & 0.0051 & 0.1783 \\
\hline $\mathrm{T}_{5}=\mathrm{T}_{1}+\mathrm{S}_{2}$ & 0.59 & 21.15 & 0.14 & 5.03 & 0.75 & 26.91 & 0.25 & 9.00 & 0.0052 & 0.1803 \\
\hline $\mathrm{T}_{6}=\mathrm{T}_{2}+\mathrm{S}_{1}$ & 0.66 & 24.25 & 0.15 & 5.54 & 0.81 & 29.74 & 0.26 & 9.58 & 0.0053 & 0.1949 \\
\hline $\mathrm{T}_{7}=\mathrm{T}_{2}+\mathrm{S}_{2}$ & 0.69 & 25.94 & 0.18 & 6.78 & 0.87 & 32.78 & 0.29 & 10.90 & 0.0053 & 0.1993 \\
\hline $\mathrm{T}_{8}=\mathrm{T}_{3}+\mathrm{S}_{1}$ & 0.73 & 28.33 & 0.18 & 7.00 & 0.89 & 34.53 & 0.29 & 11.27 & 0.0057 & 0.2212 \\
\hline $\mathrm{T}_{9}=\mathrm{T}_{3}+\mathrm{S}_{2}$ & 0.78 & 30.95 & 0.19 & 7.57 & 0.96 & 38.10 & 0.31 & 12.31 & 0.0059 & 0.2343 \\
\hline Mean & 0.56 & 19.83 & 0.15 & 5.16 & 0.70 & 24.95 & 0.23 & 8.24 & 0.0050 & 0.1757 \\
\hline SEm & 0.01 & 0.38 & 0.01 & 0.32 & 0.01 & 0.36 & 0.01 & 0.29 & 0.0001 & 0.0035 \\
\hline $\mathrm{CD}(5 \%)$ & 0.03 & 1.12 & 0.02 & 0.96 & 0.03 & 1.08 & 0.02 & 0.88 & 0.0002 & 0.0103 \\
\hline
\end{tabular}

Where, FYM $=$ Farm Yard Manure at $5 \mathrm{tha}^{-1}, \mathrm{Zn}_{1}=\mathrm{Zn}$ at $5 \mathrm{~kg} \mathrm{ha}^{-1}$ as $\mathrm{Zn}$-EDTA, $\mathrm{Zn}_{2}=\mathrm{Zn}$ at $10 \mathrm{~kg} \mathrm{ha}^{-1}$ as Zn-EDTA, $\mathrm{S}_{1}=\mathrm{S}$ at $20 \mathrm{~kg} \mathrm{ha}^{-1}$ as Elemental S, $\mathrm{S}_{2}=\mathrm{S}$ at $40 \mathrm{~kg} \mathrm{ha}^{-1}$ as Elemental S"

by De et al. (2014) using combination of RDF along with various doses of vermicompost, poultry manure, FYM, neem cake as treatment combinations in rapeseed. Furthermore, roots are proliferated during these stages of crop growth. As the root rhizosphere is increased, the activities of microorganisms are supposed to be increased with the liberation of exudates which are rich in carbohydrates and other energy rich food materials (Arshad and Frankenberger, 1998). The activities of ammonifying and nitrifying microorganisms liberate nitrogen from organic source to available form by the process of N-mineralization (Alexander, 1977). Although, consumption of available $\mathrm{N}$ by the growing rapeseed crop is at peak at these stages but still considerable amount remained in the soil systems. Balanced nutrition and appropriate doses of fertilizers not only encourage production of more dry matter and accumu- lation of photosynthates (Shukla et al., 2002) but also enhance the proliferation of microbial activities in soils as established by the earlier works of Mukherjee (2014) who used varying fertilizer doses $(150 \%, 100$ $\%, 50 \%$ and $25 \%$ of RDF) in maize-yellow sarson cropping system. Comparatively higher amount of available $\mathrm{N}$ is utilized by the growing rapeseed crop from the soils which had received higher doses of $\mathrm{S}$ and $\mathrm{Zn}$ along with FYM. The present results are par with earlier work carried out by Baudh and Prasad (2012) integrating separate doses of organic manure, $\mathrm{Zn}$ and $\mathrm{S}$ fertilizers with RDF in mustard.

Irrespective of treatments, available $\mathrm{P}_{2} \mathrm{O}_{5}$ decreased significantly with increase in the period of crop growth (Table 1). The decrease in available $\mathrm{P}_{2} \mathrm{O}_{5}$ with time is due to its utilization by the growing rapeseed crop. Comparatively higher amount of available $\mathrm{P}_{2} \mathrm{O}_{5}$ is ac- 
Sayan Majumder et al. / J. Appl. \& Nat. Sci. 9 (2): 1151 - 1156 (2017)

Table 4. N, P, K, S and Zn uptake by seeds of rapeseed grown under different treatment combinations.

\begin{tabular}{|c|c|c|c|c|c|c|c|c|c|c|}
\hline \multirow[b]{2}{*}{ Treatments } & \multicolumn{2}{|c|}{ Nitrogen } & \multicolumn{2}{|c|}{ Phosphorus } & \multicolumn{2}{|c|}{ Potassium } & \multicolumn{2}{|c|}{ Sulphur } & \multicolumn{2}{|c|}{ Zinc } \\
\hline & N\% & $\begin{array}{c}\text { Uptake } \\
\left(\mathrm{kg} \mathrm{ha}^{-1}\right)\end{array}$ & $\mathbf{P \%}$ & $\begin{array}{c}\text { Uptake } \\
\left(\mathrm{kg} \mathrm{ha}^{-1}\right)\end{array}$ & K\% & $\begin{array}{c}\text { Uptake } \\
\left(\mathrm{kg} \mathrm{ha}^{-1}\right)\end{array}$ & S\% & $\begin{array}{c}\text { Uptake } \\
\left(\mathrm{kg} \mathrm{ha}^{-1}\right)\end{array}$ & Zn \% & $\begin{array}{l}\text { Uptake } \\
\left(\mathrm{kg} \mathrm{ha}^{-1}\right)\end{array}$ \\
\hline $\mathrm{T}_{0}=$ Soil & 1.62 & 15.59 & 0.12 & 1.16 & 1.22 & 11.74 & 0.45 & 4.44 & 0.0050 & 0.0385 \\
\hline $\mathrm{T}_{1}=$ Soil $+\mathrm{FYM}$ & 1.91 & 19.35 & 0.15 & 1.52 & 1.51 & 15.30 & 0.47 & 4.77 & 0.0051 & 0.0426 \\
\hline $\mathrm{T}_{2}=\mathrm{T}_{1}+\mathrm{Zn}_{1}$ & 2.02 & 21.36 & 0.16 & 1.68 & 1.95 & 20.28 & 0.50 & 5.29 & 0.0056 & 0.0487 \\
\hline $\mathrm{T}_{3}=\mathrm{T}_{1}+\mathrm{Zn}_{2}$ & 2.15 & 23.92 & 0.16 & 1.80 & 2.13 & 23.69 & 0.51 & 5.69 & 0.0059 & 0.0558 \\
\hline $\mathrm{T}_{4}=\mathrm{T}_{1}+\mathrm{S}_{1}$ & 2.35 & 28.90 & 0.18 & 2.22 & 2.30 & 28.28 & 0.57 & 7.01 & 0.0060 & 0.0628 \\
\hline $\mathrm{T}_{5}=\mathrm{T}_{1}+\mathrm{S}_{2}$ & 2.47 & 31.24 & 0.19 & 2.42 & 2.45 & 30.98 & 0.60 & 7.60 & 0.0060 & 0.0659 \\
\hline $\mathrm{T}_{6}=\mathrm{T}_{2}+\mathrm{S}_{1}$ & 2.51 & 33.05 & 0.19 & 2.52 & 2.64 & 34.77 & 0.60 & 7.92 & 0.0061 & 0.0699 \\
\hline $\mathrm{T}_{7}=\mathrm{T}_{2}+\mathrm{S}_{2}$ & 2.59 & 34.65 & 0.21 & 2.82 & 2.79 & 37.32 & 0.62 & 8.31 & 0.0062 & 0.0710 \\
\hline $\mathrm{T}_{8}=\mathrm{T}_{3}+\mathrm{S}_{1}$ & 2.65 & 36.66 & 0.22 & 3.05 & 2.84 & 39.30 & 0.63 & 8.73 & 0.0065 & 0.0790 \\
\hline $\mathrm{T}_{9}=\mathrm{T}_{3}+\mathrm{S}_{2}$ & 2.69 & 38.21 & 0.23 & 3.27 & 2.89 & 41.04 & 0.66 & 9.38 & 0.0066 & 0.0838 \\
\hline Mean & 2.30 & 28.29 & 0.18 & 2.25 & 2.27 & 28.27 & 0.56 & 6.91 & 0.0059 & 0.0618 \\
\hline SEm & 0.01 & 0.48 & 0.01 & 0.12 & 0.01 & 0.45 & 0.01 & 0.16 & 0.0005 & 0.0014 \\
\hline $\mathrm{CD}(5 \%)$ & 0.02 & 1.43 & 0.02 & 0.35 & 0.02 & 1.35 & 0.02 & 0.48 & 0.0002 & 0.0040 \\
\hline
\end{tabular}

Where, FYM $=$ Farm Yard Manure at $5 \mathrm{tha}^{-1}, \mathrm{Zn}_{1}=\mathrm{Zn}$ at $5 \mathrm{~kg} \mathrm{ha}^{-1}$ as Zn-EDTA, $\mathrm{Zn}_{2}=\mathrm{Zn}$ at $10 \mathrm{~kg} \mathrm{ha}^{-1}$ as Zn-EDTA, $\mathrm{S}_{1}=\mathrm{S}$ at $20 \mathrm{~kg} \mathrm{ha}^{-1}$ as Elemental $\mathrm{S}, \mathrm{S}_{2}=\mathrm{S}$ at $40 \mathrm{~kg} \mathrm{ha}^{-1}$ as Elemental $\mathrm{S}$

cumulated in soils at flowering stage of rapeseed is due to mineralization of organic P from the FYM treated systems. The results find support of earlier works carried out by Reddy et al. (1999). Combined application of $\mathrm{S}$ and $\mathrm{Zn}$ along with FYM significantly increased available $\mathrm{P}_{2} \mathrm{O}_{5}$ content in soils at flowering stage of rapeseed. Accumulation of higher amount of available $\mathrm{P}_{2} \mathrm{O}_{5}$ in soils treated with higher doses of $\mathrm{S}$ and $\mathrm{Zn}$ along with FYM is due to the creation of favourable microenvironment for P-solubilizing microorganisms which solubilizes organic P from FYM treated systems (Mafongoya et al., 2000). The decrease in available $\mathrm{P}_{2} \mathrm{O}_{5}$ with the advancement of crop growth is not only due to its utilization by rapeseed (Urricariet et al., 1995) but also due to conversion of some amount of available $\mathrm{P}_{2} \mathrm{O}_{5}$ into organic form and fixation by other soil components (Qiu et al., 2004).

Available $\mathrm{K}_{2} \mathrm{O}$ tended to increase in soils treated identically either with $\mathrm{Zn}$ or S along with FYM up to pod formation stage and thereafter showed a decreasing trend at harvesting stage of rapeseed (Table 1). However, combined application of $\mathrm{Zn}$ and $\mathrm{S}$ along with FYM showed a different trend of results. Irrespective of addition of different doses of $\mathrm{S}$ and $\mathrm{Zn}$, available $\mathrm{K}_{2} \mathrm{O}$ tended to decrease significantly throughout the cropping season of mustard. Balanced nutrition of crops encouraged both vegetative and root growth of rapeseed (De et al., 2014) which in turn utilizes more amount of available $\mathrm{K}_{2} \mathrm{O}$ from soils throughout the cropping season. The results of the present investigation are in conformity with earlier study carried out by Basak and Mitra (2002). A consistent decrease in available $\mathrm{K}_{2} \mathrm{O}$ is observed in soils which received combined application of higher doses of $\mathrm{S}$ and $\mathrm{Zn}$ fertilizers along with FYM throughout the cropping period of rapeseed.

Results in Table 2 revealed that irrespective of treatments, oxidizable organic carbon decreased signifi- cantly from flowering to pod formation and thereafter increased up to harvesting stage of rapeseed. Organic carbon content tended to decrease significantly at pod formation stage because of its utilization by the growing rapeseed. The increase in organic carbon in soils at harvesting stage is due to accumulation of dead roots and rootlets of rapeseed crop (Gaudinski et al., 2000) along with incorporation of dead cells of microorganisms. Comparatively higher amount of organic carbon is accumulated in soils treated combinedly with $\mathrm{S}$ and Zn fertilizers along with FYM. Balanced fertilization encourages both vegetative and root growth of rapeseed (Datta et al., 2009) and as such more number of roots and rootlets are decayed which are converted to organic forms showing comparatively higher amount of accumulation of organic carbon in soils (Swarup and Yaduvanshi, 2000).

Irrespective of treatments, $\mathrm{SO}_{4}{ }^{-2}$ tended to decrease significantly with increase in the period of crop growth (Table 2). Furthermore, addition of S-fertilizer increased $\mathrm{SO}_{4}{ }^{-2}$ content of soils. Addition of lower and higher doses of S-fertilizer increased $\mathrm{SO}_{4}{ }^{-2}$ content by $7.51 \mathrm{~kg} \mathrm{ha}^{-1}$ and $10.17 \mathrm{~kg} \mathrm{ha}^{-1}$ in absence of added $\mathrm{Zn}$ compared to control. However, addition of either doses of S-fertilizer further increased $\mathrm{SO}_{4}{ }^{-2}$ content in soils in presence of either doses of $\mathrm{Zn}$ at the flowering stage of rapeseed. However, the increment is maximum in soils which received higher dose of $\mathrm{S}$ and $\mathrm{Zn}$. The increase of $\mathrm{SO}_{4}{ }^{-2}$ in soils treated with elemental $\mathrm{S}$ is obvious. Higher amount of accumulation of $\mathrm{SO}_{4}^{-2}$ in FYM treated system is due to the mineralization of organic $\mathrm{S}$ present in FYM (Wang et al., 2006). The decrease in $\mathrm{SO}_{4}{ }^{-2}$ with advancement of growth of rapeseed is due to its utilization by the growing crop. Higher amount of utilization of $\mathrm{SO}_{4}^{-2}$ by the rapeseed crop treated combinedly with higher doses of S and Zn along with FYM is due to supply of balanced and higher amount of available nutrients to plants resulting more height and 
Table 5. Seed yield $\left(\mathrm{q} \mathrm{ha}^{-1}\right)$, Protein (\%) and Oil (\%) content of rapeseed grown under different treatment combinations.

\begin{tabular}{|c|c|c|c|}
\hline \multirow{2}{*}{ Treatments } & \multirow{2}{*}{$\begin{array}{l}\text { Seed } \\
\text { Yield }\end{array}$} & \multicolumn{2}{|c|}{ Quality parameters } \\
\hline & & Protein Content & Oil Content \\
\hline $\mathrm{T}_{0}=$ Soil & 9.62 & 17.20 & 35.31 \\
\hline $\mathrm{T}_{1}=$ Soil $+\mathrm{FYM}$ & 10.13 & 18.23 & 40.54 \\
\hline $\mathrm{T}_{2}=\mathrm{T}_{1}+\mathrm{Zn}_{1}$ & 10.58 & 18.79 & 40.30 \\
\hline $\mathrm{T}_{3}=\mathrm{T}_{1}+\mathrm{Zn}_{2}$ & 11.12 & 19.15 & 40.92 \\
\hline $\mathrm{T}_{4}=\mathrm{T}_{1}+\mathrm{S}_{1}$ & 12.29 & 19.22 & 41.16 \\
\hline $\mathrm{T}_{5}=\mathrm{T}_{1}+\mathrm{S}_{2}$ & 12.64 & 19.89 & 41.57 \\
\hline $\mathrm{T}_{6}=\mathrm{T}_{2}+\mathrm{S}_{1}$ & 13.16 & 20.15 & 41.69 \\
\hline $\mathrm{T}_{7}=\mathrm{T}_{2}+\mathrm{S}_{2}$ & 13.37 & 20.76 & 42.66 \\
\hline $\mathrm{T}_{8}=\mathrm{T}_{3}+\mathrm{S}_{1}$ & 13.83 & 21.43 & 42.35 \\
\hline $\mathrm{T}_{9}=\mathrm{T}_{3}+\mathrm{S}_{2}$ & 14.2 & 21.82 & 43.20 \\
\hline Mean & 12.09 & 19.66 & 40.97 \\
\hline SEm & 0.19 & 0.01 & 0.01 \\
\hline $\mathrm{CD}(5 \%)$ & 0.57 & 0.03 & 0.03 \\
\hline
\end{tabular}

Where, FYM=Farm Yard Manureat $5 \mathrm{tha}^{-1}, \mathrm{Zn}_{1}=\mathrm{Znat} 5 \mathrm{kgha}^{-1}$ asZn-EDTA, $Z_{2}=Z_{n}$ nat $10 \mathrm{kgha}^{-1}$ as Zn-EDTA, S $\mathrm{S}_{1}=$ Sat 20 $\mathrm{kgha}^{-1}$ as Elemental S, $\mathrm{S}_{2}=$ Sat $40 \mathrm{kgha}^{-1}$ as Elemental $\mathrm{S}$

dry matter accumulation (Shukla et al., 2002; Singh and Pal, 2011).

DTPA-extractable $\mathrm{Zn}$ tended to increase slightly in soils which are amended either with $\mathrm{Zn}$ or with S fertilizer along with FYM from flowering to pod formation stage but decreased thereafter up to harvesting stage of rapeseed (Table 2). However, soils treated combinedly with $\mathrm{Zn}$ and $\mathrm{S}$ fertilizers along with FYM showed a decreasing trend of DTPA-extractable $\mathrm{Zn}$ in soils throughout the cropping period of rapeseed under these treatments. This is due to proper growth of crop in presence of inorganic and organic fertilizers (Aswal and Yadav, 2007).

$\mathrm{N}, \mathrm{P}, \mathrm{K}, \mathrm{S}$ and $\mathrm{Zn}$ percentages and $\mathrm{N}, \mathrm{P}, \mathrm{K}, \mathrm{S}$ and $\mathrm{Zn}$ uptake by stover and seeds of rapeseed differ significantly grown under different treatment combinations (Tables 3 and 4). Addition of FYM along with recommended doses of $\mathrm{N}, \mathrm{P}$ and $\mathrm{K}$ in combination with either $\mathrm{Zn}$ or $\mathrm{S}$ or together not only increased dry matter production but also increased uptake of all the nutrients by crops. Treatments which received combined application of $\mathrm{Zn}$ and S along with FYM and recommended doses of $\mathrm{N}, \mathrm{P}$ and $\mathrm{K}$ fertilizers showed higher values of $\mathrm{N}, \mathrm{P}, \mathrm{K}, \mathrm{S}$ and $\mathrm{Zn}$ uptake by both stover and seed. Besides, combined application of $\mathrm{Zn}$ and $\mathrm{S}$ with FYM further improved uptake of nutrients mainly due to better growth and dry matter accumulation (Singh and Pal, 2011). The balanced nutrition also exerted the synergistic effect on uptake of other nutrients (Ahmad et al., 2007). As the uptake data is obtained by multiplying percentage data with that of dry matter yield, so where dry matter production is higher, uptake will be of higher order. Furthermore, balanced nutrition encourages more vegetative growth and in turn acquisition of higher amount of nutrients in plant. These results corroborate with previous findings of Tripathi et al. (2010) who incorporated RDF, $\mathrm{S}, \mathrm{ZnSO}_{4}$, Boron, Azotobacter and FYM as treatments in mustard and Singh and Pal (2011) who considered application of $\mathrm{RDF}, \mathrm{ZnSO}_{4}, \mathrm{FYM}$ and Azotobacteras treatments in the experiment with mustard.

Integrated application of recommended doses of fertilizers along with FYM, S and Zn significantly increased oil and protein content as well as seed yield compared to alone application of any of the chemical or organic fertilizer (Table 5). However, the highest protein and oil content as well as seed yield were recorded in rapeseed crop grown in soils treated with recommended doses of N, P and $\mathrm{K}$ along with FYM as well as higher doses of $\mathrm{S}$ and $\mathrm{Zn}$ fertilizers. The increase in oil content under FYM, S, and Zn treatment $\left(\mathrm{T}_{9}\right)$ might be due to the increased availability of $\mathrm{S}$ and $\mathrm{Zn}$ that are involved in increased conversion of primary fatty acid metabolites to the end products of fatty acid as supported by earlier works (Tripathi et al., 2010; Singh and Pal, 2011). Furthermore, higher levels of chemical fertilizer application improved $\mathrm{N}$ availability that helped in higher protein production and made potential deficiency of carbohydrates (Shukla et al., 2002). The increase in oil content with sulphur fertilization may be attributed due to its role in oil synthesis. Highest seed yield in rapeseed grown in soils treated combinedly with FYM and higher doses of $\mathrm{S}$ and $\mathrm{Zn}$ along with recommended doses of $\mathrm{N}, \mathrm{P}$ and $\mathrm{K}$ fertilizers is due to formation of more number of branches under above treatment which may be correlated with more plant height and dry matter accumulation as a result of better nutrient supply to the test crop rapeseed.

\section{Conclusion}

Combined application of higher doses $\mathrm{S}\left(40 \mathrm{~kg} \mathrm{ha}^{-1}\right)$ and $\mathrm{Zn}\left(10 \mathrm{~kg} \mathrm{ha}^{-1}\right)$ along with recommended doses of $\mathrm{N}, \mathrm{P}$ and $\mathrm{K}$ as well as FYM not only increased organic carbon by $42.65 \%$ (over that of control) and available $\mathrm{SO}_{4}^{-2}$ by $77.29 \%$ (over that of control) but also enhanced the yield by $47.61 \%$ (over that of control) and quality (protein content by $26.86 \%$ and oil content by $23.34 \%$ over that of control) in yellow sarson.

\section{REFERENCES}

Ahmad, G., Jan, A., Arif, M., Jan, M. T. and Khattak, R. A. (2007). Influence of nitrogen and sulfur fertilization on quality of canola (Brassica napus L.) under rain fed conditions. Journal of Zhejiang University - Science B: Biomedicine \& Biotechnology, 8:731-737

Alexander, M. (1977). Introduction to Soil Microbiology. John Willy and Sons Ltd.

Ameta, V., Chaplot, P. C., Sumeriya, H. K. (2014). Response of elite mustard [Brassica juncea (L.) Czern. and Coss.] varieties to balanced fertilization and agrochemicals. Annals of Agri Bio Research, 19(1): 49-54

Arbad, B. K. and Ismail, S. (2011). Effects of integrated nutrient management on soyabean (Glycine max)- 
safflower (Carthamustinctorius) cropping system. Indian J .Agron, 56: 340-345

Arshad, M. and Frankenberger, W. Jr. (1998). Plant growth regulating substances in the rhizoshere: microbial production and functions. Advances in Agronomy, 62:145151

Aswal, S. and Yadav, K. K. (2007). Effect of sulphur and zinc on growth, yield, quality and net returns of mustard [Brassica juncea (L.) Czern and Coss]. Current Agriculture, 31(1/2): 127-129

Basak, R. K. and Mitra, S. (2002). Available potassium status of West Bengal soil. Environment and Ecology, 20(4): 991-992

Baudh, A. K. and Prasad, G. (2012). Interaction effect of different dose of sulphur and zinc with nitrogen, phosphorus and organic manure on growth and productivity of mustard (Brassica campestris). Indian Journal of Scientific Research, 3(1): 141-144

Chesnin, L. and Yien, C. H. (1951). Turbidimetric determination of Available Sulphate. Proc. Soil Sci Am., 15: 149-151

Datta, J. K., Banerjee, A., Sikdar, M. S. and Gupta, S. (2009). Impact of Combined Exposure of Chemical Fertilizer, Bio-fertilizer and Compost on Growth, Physiology and Productivity of Brassica campestris in Old Alluvial Soil. Journal of Environmental Biology, 30(5): 797-800

De, B., Das, B., Das, B. Sinha, A. C. (2014). Effect of integrated nutrient management on yield, nutrient uptake and economics of rapeseed (Brassica campestris var. yellow sarson) in terai region of West Bengal. Journal of Crop and Weed,10(1): 69-72

Esilaba, A. O., Byalebeka, J. B., Delve, R. J., Okalebo, J. R., Ssenyange, D., Mbalule, M. and Ssali, H. (2004). On farm testing of integrated nutrient management strategies in eastern Uganda. Agric Syst., 86: 144-165

Gupta, V., Sharma, A., Abrol, J. V., Singh, B. and Singh, M. (2014). Effects of F Integrated Nutrient Management on growth and yield of Mustard (Zea mays L.)Gobhi Sarson (Brassica napus L.) cropping system in sub-tropical region under foothills of North-West Himalayas. Bangladesh J. Bot., 43(2): 147-155

Gaudinski, J. B., Trumbore, S. E., Davidson, E. A. and Zheng, S. (2000). Soil carbon cycling in a temperate forest: radiocarbon estimates of residence time, sequestration rates and portioning of fluxes. Biogeochemistry, 51:33-69

Jackson, M. L. (1973). Soil chemical analysis, Prentice Hall of India Pvt. Ltd, New Delhi Pp. 45-226

Lowry, O. H., Rosebrough, N. J., Farr, A. L. and Randall, R. J. (1951). Protein measurement with the Folin phenol reagent. J. Biol. Chem., 193: 265-275

Mafongoya, P. L., Barak, P. and Reed, J. D. (2000). Carbon, nitrogen and phosphorus mineralization of tree leaves and manure, Biol. Fertil. Soils, 30: 298-305
Mahajan, A. and Sharma, R. (2005). Integrated nutrient management (INM) System - Concept, need and future strategy. Agrobios newsletter, 4(3): 29-32

Mukherjee, D. (2014). Influence of integrated nutrient management on productivity, nutrient uptake and economics of maize (Zea mays)-yellow sarson (Brassica rapa) cropping system under rainfed mid hill condition. Indian Journal of Agronomy. 59(2): 221-228

Piper, C. S. 1967. Soil and plant analysis. Asia Publishing House, Bombay, India.

Qiu, H. Y., Rong, S. Q., Min, K. H., Sheng, X. Y. and Ziang, W. X. (2004). Effect of soil moisture content and phosphorus application on phosphorus nutrition of rice cultivated in different water regime systems. Journal of Plant Nutrition, 27(12): 2259-2272

Rai, S. K., Charak, D. and Bharat, R. (2016). Scenario of Oilseed crops across the globe. Plant Archive, 16(1): $125-132$

Rao, S. A. and Reddy, S. K. (2005). Emerging strategies for sustaining higher productivity and ensuring soil quality under intensive agriculture. Indian Journal of Fertilizers, 1(4): 61-76

Reddy, D. D., Rao, A. S., Reddy, K. S. and Takkar, P. N. (1999). Yield sustainability and phosphorus utilization in soyabean-wheat system on vertisols in response to integrated use of manure and fertilizer phosphorus. Field Crops Res., 62: 181-190

Shukla, D. K., Shukla, A., Mahapatra, B. S. and Singh, R. P. (2002). Response of yellow sarson varieties to different nitrogen levels in Tarai region of U.P. Annals of Agricultural Research, 23(4): 726-727

Singh, S. P. Pal, M. S. (2011). Effect of integrated nutrient management on productivity, quality, nutrient uptake and economics of mustard (Brassica juncea). Indian Journal of Agronomy, 56(4): 81-387

Soxhlet, F. (1879). Die gewichts-analytische Bestimmung des Milchfettes. Dinglers Polytechnisches Journal, 232: 461

Swarup, A. and Yaduvanshi, N. P. S. (2000). Effects of Integrated nutrient Management on soil properties and yield of rice in alkali soils. J. Indian Soc. Soil Sci., 48(2): 279 $-282$

Tripathi, M. K., Chaturvedi, S., Shukla, D. K. and Mahapatra, B. S. (2010). Yield, performance and quality of Indian mustard (Brassica juncea) as affected by integrated nutrient management. Ind. J. Agron., 55: 138-142

Urricariet, A. S., Zubilaga, M. S., Zubilaga, M. M. and Lavado, R. S. (1995). Nitrogen, phosphorus and potassium uptake of two rapeseed cultivars in an argentinean soil. Journal of Plant Nutrition, 18(2): 305-315

Wang, J., Solomon, D., Lehmann, J., Zhang, X. and Amelung, W. (2006). Soil organic sulfur forms and dynamics in the Great Plains of North America as influenced by long-term cultivation and climate. Geoderma, 133: $160-172$ 